\title{
PERLINDUNGAN HUKUM TERHADAP KONSUMEN PEER TO PEER LENDING ATAS PERBUATAN MELAWAN HUKUM YANG DILAKUKAN OLEH DEBT COLLECTOR
}

\author{
Deza Pasma Juniar ${ }^{1}$, Agus Suwandono ${ }^{2}$, Helitha Novianty Muchtar ${ }^{3}$ \\ 1Fakultas Hukum, Universitas Padjadjaran, email: deza16001@mail.unpad.ac.id \\ ${ }^{2}$ Fakultas Hukum, Universitas Padjadjaran \\ ${ }^{3}$ Fakultas Hukum, Universitas Padjadjaran
}

\begin{abstract}
ABSTRAK
Otoritas Jasa Keuangan (OJK) dalam melaksanakan fungsi pengaturan telah mengatur peer to peer lending di dalam Peraturan Otoritas Jasa Keuangan No.77/POJK.01/2016 Tentang Layanan Pinjam Meminjam Berbasis Teknologi Informasi (POJK LPMUBTI), namun di dalam POJK LPMUBTI tidak mengatur mengenai penggunaan pihak ketiga atau debt collector dalam melakukan penagihan kepada konsumen. Hal tersebut hanya diatur di dalam Pedoman Perilaku yang dibuat oleh Asosiasi Fintech Pendanaan Bersama (AFPI) dan masih terdapat pelanggaran dalam melakukan penagihan yang dilakukan oleh debt collector peer to peer lending kepada konsumen. Penelitian ini dilakukan untuk menganalisis terkait dengan pengaturan penggunaan debt collector dalam melakukan penagihan dan penyelesaian sengketa yang dapat dilakukan oleh konsumen terhadap debt collector yang melakukan perbuatan melawan hukum dalam penagihan. Metode yang digunakan adalah metode pendekatan yuridis normatif yaitu melakukan penelitian dengan menggunakan peraturan-peraturan dan literature terkait. Hasil dari penelitian menunjukkan bahwa pengaturan terkait dengan penggunaan debt collector belum diatur oleh Otoritas Jasa Keuangan di dalam suatu Peraturan Otoritas Jasa Keuangan sehingga menimbulkan ketidakpastian hukum bagi konsumen peer to peer lending dan konsumen dapat melakukan penyelesaian sengketa melalui 2 tahapan yaitu dengan melakukan pengaduan kepada penyelenggara peer to peer lending (internal dispute resolution) dan melalui pengadilan atau luar pengadilan (external dispute resolution) berdasarkan Peraturan Otoritas Jasa No.1/POJK.07/2013 Tentang Perlindungan Konsumen Sektor Jasa Keuangan.
\end{abstract}

\section{ARTICLE INFO}

\section{Kata Kunci:}

Debt collector; Otoritas

Jasa Keuangan; Peer to

Peer Lending

\section{Cite this paper:}

Deza Pasma Juniar, A. S.

,. H. N. M., 2020.

Perlindungan Hukum

Terhadap Konsumen

Peer to Peer Lending

Atas Perbuatan

Melawan Hukum yang

Dilakukan Oleh Debt

Collector. Widya

Yuridika: Jurnal Hukum, $3(2)$.

\section{PENDAHULUAN}

Indonesia saat ini sedang menghadapi revolusi industri 4.0, dengan adanya revolusi industri 4.0 kegiatan ekonomi yang ada di Indonesia telah berkembang secara digital. Dengan berkembangnya ekonomi secara digital memberikan kemudahan pada manusia 
dalam melakukan kegiatan perekonomian. Kegiatan perekonomian dapat dilakukan dimanapun secara cepat, mudah dan online hanya dengan melalui internet, seperti belanja secara online, memesan transportasi secara online dan juga saat ini sudah mulai berkembang financial technology (fintech).

Fintech dapat diartikan sebagai pemanfaatan perkembangan teknologi informasi untuk meningkatkan layanan di industri keuangan seperti perbankan maupun perusahaan rintisan (start up). ${ }^{1}$ Fintech mempunyai berbagai macam jenis, pada sektor pembiayaan dan investasi terdapat fintech Peer to Peer Lending, Crowdfunding, Supply Chain Finance dan lain-lain. Selanjutnya, pada sektor pembayaran terdapat Mobile Banking, Mobile and Online Wallet, E-commerce Payment. ${ }^{2}$

Jenis fintech yang berkembang pesat saat ini di Indonesia adalah pada sektor pembiayaan dan investasi yaitu Peer to Peer Lending. Peer to peer lending dan Bank konvensional merupakan 2 hal yang berbeda, bank adalah badan usaha yang menghimpun dana dari masyarakat dalam bentuk kredit dan/atau bentuk-bentuk lainnya dalam rangka meningkatkan taraf hidup ${ }^{3}$, sedangkan Peer to Peer Lending adalah penyelenggaraan layanan jasa keuangan untuk mempertemukan pemberi pinjaman dengan penerima pinjaman. ${ }^{4}$

Pelaksanaan peer to peer lending saat ini diatur dan diawasi oleh Otoritas Jasa Keuangan, Otoritas Jasa Keuangan mempunyai dua fungsi yaitu melakukan Pengaturan dan pengawasan di sektor jasa keuangan. ${ }^{5}$ Secara khusus mengenai peer to peer lending, Otoritas Jasa Keuangan telah mengaturnya di dalam Peraturan Otoritas Jasa Keuangan No.77/P0JK.01/2016 Tentang Layanan Pinjam Meminjam Berbasis Teknologi Informasi (POJK LPMUBTI). Otoritas Jasa Keuangan dalam melakukan pengawasan terhadap jalannya peer to peer lending telah menunjuk Asosiasi Fintech Pendanaan Bersama Indonesia (AFPI) sebagai mitra strategis. AFPI mempunyai kewenangan untuk membuat suatu Pedoman Perilaku yang mengatur aturan tambahan yang tidak diatur di dalam POJK LPMUBTI.

Pedoman perilaku mengatur beberapa aturan tambahan dalam penyelenggaraan peer to peer lending legal yang tidak terdapat di dalam POJK LPMUBTI, salah satu aturan tambahan di dalam Pedoman Perilaku yaitu mengenai penggunaan pihak ketiga atau debt collector dalam penagihan pinjaman gagal bayar kepada konsumen. Walaupun penggunaan debt collector telah diatur di dalam suatu Pedoman Perilaku tidak dapat dipungkiri terdapat permasalahan yaitu masih terdapat perbuatan melawan yang dilakukan oleh debt collector dalam melakukan penagihan seperti mengintimidasi, berkata kasar, mendatangi kantor yang menyebabkan kerugian secara materiil maupun non materiil. Selain itu, masih terdapat ketidaksamaan waktu dalam penggunaan debt collector untuk melakukan penagihan kepada konsumen.

Perbuatan melawan hukum yang dilakukan oleh debt collector peer to peer lending tidak hanya datang dari peer to peer lending ilegal tetapi juga dari peer to peer lending yang sudah legal mendapatkan izin dari Otoritas Jasa Keuangan (OJK). Tidak diaturnya

\footnotetext{
1 Departemen Perlindungan konsumen, "Kajian Perlindungan Konsumen Sektor Jasa Keuangan: Perlindungan Konsumen Pada Fintech", diambil dari https://konsumen.ojk.go.id/MinisiteDPLK/images/upload/201807131451262.\%20Fintech.pdf 
mengenai penggunaan debt collector di dalam suatu Peraturan Otoritas Jasa Keuangan menimbulkan pertanyaan terkait dengan kepastian hukum dan perlindungan hukum bagi konsumen terhadap debt collector yang sewenang-wenang dalam melakukan penagihan. Tujuan penelitian ini untuk menganalisis terkait dengan pengaturan penggunaan debt collector dalam melakukan penagihan kepada konsumen dan juga penyelesaian sengketa yang dapat dilakukan oleh konsumen terhadap perbuatan melawan hukum yang dilakukan debt collector.

Metode penulisan yang digunakan adalah metode pendekatan yuridis normatif yaitu penelitian hukum yang dilakukan dengan cara mengadakan penelusuran terhadap peraturan-peraturan dan literature-literatur yang berkaitan dengan masalah yang diteliti. ${ }^{6}$ Pada penelitian hukum ini mengaitkan dengan beberapa peraturan yaitu Kitab Undang-Undang Hukum Perdata, Undang-Undang No.21 Tahun 2011 Tentang Otoritas Jasa Keuangan, Peraturan Otoritas Jasa Keuangan No.1/P0JK.07/2013 Tentang Perlindungan Konsumen Sektor Jasa Keuangan dan Peraturan No.77/P0JK.01/2016 Tentang Layanan Pinjam Meminjam Berbasis Teknologi Informasi.

\section{HASIL DAN PEMBAHASAN}

\section{Perlindungan Konsumen pada Peer To Peer Lending}

Konsumen sebagai pengguna suatu produk/jasa mempunyai hak-hak untuk mendapatkan perlindungan hukum. Perlindungan hukum terhadap konsumen pada dasarnya telah diatur di dalam Undang-Undang no. 8 Tahun 1999 Tentang Perlindungan konsumen, namun secara spesifik terkait dengan perlindungan konsumen pada sektor jasa keuangan telah diatur di dalam Peraturan Otoritas Jasa Keuangan No.1/P0JK.07/2013 Tentang Perlindungan Konsumen Sektor Jasa Keuangan.

Perlindungan konsumen merupakan istilah yang dipakai untuk menggambarkan perlindungan hukum yang diberikan kepada konsumen dalam usahanya untuk memenuhi kebutuhannya dari hal-hal yang merugikan konsumen. ${ }^{7}$ Perlindungan konsumen pada dasarnya mencakup beragam topik, tidak hanya terbatas mengenai kewajiban produk, hak privasi, praktik bisnis yang tidak adil, penipuan, kesalahan representasi, interaksi bisnis/konsumen lainnya. ${ }^{8}$

Perlindungan konsumen pada sektor jasa keuangan yaitu berupaya untuk melindungi konsumen serta pelaku usaha jasa keuangan. ${ }^{9}$ Istilah konsumen berasal dari alih Bahasa kata consumer (Inggris-Amerika) atau consumen/konsument (Belanda). Definisi konsumen menurut Black Law Dictionary yaitu10:

"a person who buys goods or service for personal, family, or house hold use, with no intention or resale; a natural person who use products for personal rather than business purpose."

Berdasarkan Pasal 1 angka 2 Peraturan Otoritas Jasa Keuangan No.1/POJK.07/2013 Tentang Perlindungan Konsumen Sektor Jasa Keuangan yang dimaksud dengan konsumen adalah pihak-pihak yang menempatkan dananya dan/atau memanfaatkan

\footnotetext{
${ }^{6}$ Soerjono Soekanto \& Sri Mamudji, Penelitian Hukum Normatif (Suatu Tinjauan Singkat), hlm. 13-14.

7 Zulham, Hukum Perlindungan Konsumen, hlm. 21

8 Sari Murti W. dan Johanes Widijantoro, "The Role Of Financial Services Authority In The Consumer Protection Amid The Growth Of Fintech Industry In Indonesia”, Mimbar Hhukum, hlm. 299

${ }^{9}$ Pasal 1 Angka 3 Peraturan Otoritas Jasa Keuangan No.1/POJK.07/2013 Tentang Perlindungan Konsumen Sektor Jasa Keuangan

10 Bryan A. Garner, Black's Law Dictionary, hlm. 335 sebagaimana dikutip didalam Zulham, Hukum Perlindungan Konsumen, hlm. 15
} 
pelayanan yang tersedia di Lembaga Jasa Keuangan antara lain nasabah pada Perbankan, pemodal di Pasar Modal, pemegang polis pada perasuransian, dan peserta pada Dana Pensiun, berdasarkan peraturan perundang-undangan di sektor jasa keuangan.

Perlindungan konsumen pada sektor jasa keuangan diatur dan diawasi oleh Otoritas Jasa Keuangan. Otoritas Jasa Keuangan merupakan suatu lembaga independen yang diresmikan pada 16 Juli tahun 2012 sesuai dengan amanah asal 34 Undang-Undang Nomor 3 Tahun 2004 Tentang Perubahan Atas Undang-Undang Nomor 23 Tahun 1999 Tentang Bank Indonesia. Pengaturan mengenai Otoritas Jasa Keuangan telah diatur di dalam Undang-Undang No.21 Tahun 2011 Tentang Otoritas Jasa Keuangan.

Otoritas Jasa Keuangan mempunyai tujuan untuk melindungi konsumen dan masyarakat pada sektor jasa keuangan. ${ }^{11}$ Pada dasarnya Otoritas Jasa Keuangan mempunyai 2 (dua) fungsi yaitu fungsi pengaturan dan pengawasan terhadap kegiatan jasa keuangan di sektor perbankan, pasar modal, asuransi, dana pensiun, lembaga pembiayaan dan lembaga jasa keuangan lainnya. ${ }^{12}$ Otoritas Jasa Keuangan dalam menjalankan fungsi pengaturan mempunyai kewenangan untuk menetapkan peraturan dan keputusan otoritas jasa keuangan berdasarkan Pasal 8 huruf $\mathrm{C}$ Undang-Undang No.11 Tahun 2011 Tentang Otoritas Jasa Keuangan.

Otoritas Jasa Keuangan untuk menjalankan fungsi pengaturan dalam perlindungan terhadap pengguna peer to peer lending, secara khusus mengenai peer to peer lending pada Peraturan Otoritas Jasa Keuangan No.77/POJK.01/2016 Tentang Layanan Pinjam Meminjam Berbasis Teknologi Informasi (POJK LPMUBTI). Peer to peer lending adalah penyelenggaraan layanan jasa keuangan untuk mempertemukan pemberi pinjaman dengan penerima pinjaman dalam rangka melakukan perjanjian pinjam meminjam dalam mata uang rupiah secara langsung melalui sistem elektronik dengan menggunakan jaringan internet. ${ }^{13}$

POJK LPMUBTI pada BAB VII mengatur terkait dengan perlindungan bagi konsumen pengguna peer to peer lending. Berdasarkan Pasal 29 POJK LPMUBTI penyelenggara wajib menyelenggarakan prinsip dasar dari perlindungan pengguna yaitu:
a. Transparansi;
b. Perlakuan adil;
c. Keandalan;
d. kerahasiaan dan keamanan data;
e. Penyelesaian sengketa pengguna secara sederhana, cepat dan biaya terjangkau.
Penyelenggara peer to peer lending dilarang menyebarkan data dan/atau informasi kepada pihak ketiga. ${ }^{14}$ Larangan tersebut dikecualikan jika pengguna memberikan persetujuan secara elektronik dan/atau diwajibkan oleh ketentuan peraturan perundang-undangan. ${ }^{15}$

\footnotetext{
11 Pasal 4 Undang-Undang No.21 Tahun 2011 Tentang Otoritas Jasa keuangan

12 Pasal 5 Undang-Undang No.21 Tahun 2011 Tentang Otoritas Jasa Keuangan

13 Pasal 1 Angka 3 Peraturan Otoritas Jasa Keuangan No.77/P0JK.01/2016 Tentang Layanan Pinjam Meminjam Berbasis Teknologi Informasi

14 Pasal 39 (1) Peraturan Otoritas Jasa Keuangan No.1/POJK.07/2013 Tentang Perlindungan Konsumen

Sektor Jasa Keuangan

15 Pasal 39 (2) Peraturan Otoritas Jasa Keuangan No.1/POJK.07/2013 Tentang Perlindungan Konsumen Sektor Jasa Keuangan
} 


\section{Penerapan Pengaturan Penggunaan Debt collector pada Peer to Peer Lending}

Otoritas Jasa Keuangan dalam menjalankan fungsi pengaturan mempunyai kewenangan untuk menetapkan peraturan dan keputusan otoritas jasa keuangan berdasarkan Pasal 8 huruf C Undang-Undang No.11 Tahun 2011 Tentang Otoritas Jasa Keuangan. Untuk melaksanakan fungsi pengaturan dalam peer to peer lending, Otoritas Jasa Keuangan telah membuat Peraturan Otoritas Jasa Keuangan No.77/P0JK.01/2016 Tentang Layanan Pinjam Meminjam Berbasis Teknologi Informasi.

Peraturan Otoritas Jasa Keuangan No.77/P0JK.01/2016 Tentang Layanan Pinjam Meminjam Berbasis Teknologi Informasi mengatur mengenai penyelenggaraan pelayanan peer to peer lending seperti permodalan, kepemilikan, status badan hukum penyelenggara peer to peer lending, cara pendaftaran dan permohonan izin penyelenggaraan peer to peer lending, hak dan kewajiban para pihak serta sanksi-sanksi bagi pelanggar peer to peer lending. Peraturan Otoritas Jasa Keuangan No.77/P0JK.01/2016 Tentang Layanan Pinjam Meminjam Berbasis Teknologi Informasi menjadi dasar hukum bagi penyelenggaraan peer to peer lending di Indonesia dan juga sebagai perlindungan bagi konsumen pengguna peer to peer lending di Indonesia.

Otoritas Jasa Keuangan dalam melaksanakan fungsi pengawasan terhadap jalannya peer to peer lending di Indonesia yaitu dengan menunjuk Asosiasi Fintech Pendanaan Bersama Indonesia (AFPI). Pembentukan AFPI berawal dari aspirasi para penyelenggara terkait dengan pentingnya kehadiran asosiasi untuk menjalankan fungsi pengawasan dan pengaturan kepada para penyelenggara peer to peer lending di Indonesia. ${ }^{16}$ Selain itu, pembentukan AFPI sesuai dengan Pasal 48 Peraturan Otoritas Jasa Keuangan No.77/POJK.01/2016 Tentang Layanan Pinjam Meminjam Berbasis Teknologi Informasi yang mewajibkan para penyelenggara terdaftar pada asosiasi yang telah ditunjuk oleh $0 \mathrm{JK}$.

AFPI merupakan mitra strategis Otoritas Jasa Keuangan untuk mewadahi penyelenggaraan peer to peer lending di Indonesia yang diresmikan pada tanggal 8 Maret 2019. Pembentukan AFPI didasarkan atas surat dari Otoritas Jasa Keuangan No. S-5/D.05/2019 yang dikeluarkan pada tanggal 17 Januari 2019. AFPI mempunyai kewenangan salah satunya untuk membuat Pedoman Perilaku Pemberian Layanan Pinjam Meminjam Uang Berbasis Teknologi Informasi Secara Bertanggung Jawab.

Pedoman Perilaku mengatur beberapa hal-hal yang tidak diatur pada Peraturan Otoritas Jasa Keuangan No.77/P0JK.01/2016 Tentang Layanan Pinjam Meminjam Berbasis Teknologi Informasi seperti mengenai penggunaan debt collector dalam penagihan pinjaman gagal bayar pada peer to peer lending dan tata cara debt collector dalam melakukan penagihan. Pada dasarnya pengaturan mengenai debt collector memang tidak diatur secara khusus oleh suatu peraturan perundangundangan dan hanya mengacu pada Pasal 1792 Kitab Undang-Undang Hukum Perdata mengenai pemberian kuasa.

Penggunaan debt collector pada peer to peer lending untuk menagih pinjaman gagal bayar berdasarkan pedoman perilaku diperbolehkan oleh AFPI. Debt collector yang diperbolehkan oleh AFPI adalah perusahaan jasa pelaksanaan penagihan yang telah terdaftar di AFPI dan memiliki sertifikat untuk melakukan penagihan kepada

16 Prayogo Ryza, “AFPI Ditunjuk OJK Sebagai Asosiasi Resmi Penylenggara Layanan P2P Lending”, diambil dari https://dailysocial.id/post/afpi-resmi-p2p-lending 
konsumen yang dikeluarkan oleh AFPI. ${ }^{17}$ Penggunaan jasa debt collector hanya dapat dilakukan untuk tagihan yang telah melewati batas keterlambatan 90 (hari) dari tanggal jatuh tempo pinjaman. ${ }^{18}$ Debt collector dilarang menggunakan kekerasan fisik dan mental dalam melakukan penagihan pinjaman gagal bayar kepada konsumen. ${ }^{19}$ Pedoman perilaku yang dibentuk oleh AFPI tidak termasuk ke dalam suatu peraturan perundang-undangan sebagaimana dimaksud di dalam Pasal 8 (1) Undang-Undang Nomor 12 Tahun 2011 Tentang Pembentukan Peraturan Perundang-Undangan.

Penagihan menggunakan pihak ketiga atau debt collector juga dilakukan pada bidang perbankan dan bidang perusahaan pembiayaan. Untuk perbandingan pada bidang perbankan walaupun terdapat etika penagihan yang dibuat oleh Asosiasi Penyelenggara Alat Pembayaran Menggunakan Kartu tetapi Bank Indonesia tetap mengatur mengenai penggunaan debt collector dan tata cara debt collector dalam melakukan penagihan pinjaman gagal bayar dalam kartu kredit di dalam suatu peraturan perundang-undangan yaitu :

a. Peraturan Bank Indonesia Nomor 11/11/PBI/2009 tentang Penyelenggaraan Kegiatan Alat Pembayaran dengan Menggunakan Kartu ("PBI 11/2009") sebagaimana yang telah diubah oleh Peraturan Bank Indonesia No. 14/2/PBI/2012 tentang Perubahan Atas Peraturan Bank Indonesia Nomor 11/11/PBI/2009 tentang Penyelenggaraan Kegiatan Alat Pembayaran dengan Menggunakan Kartu.

b. Surat Edaran Bank Indonesia Nomor 14/17/DASP tanggal 7 Juni 2012 perihal Perubahan atas Surat Edaran Bank Indonesia Nomor 11/10/DASP perihal Penyelenggaraan Kegiatan Alat Pembayaran dengan Menggunakan Kartu (SEBI 2012)

Pengaturan mengenai penagihan menggunakan debt collector pada bidang perusahaan pembiayaan telah diatur oleh Otoritas Jasa Keuangan di dalam Pasal 49 Peraturan Otoritas Jasa Keuangan Nomor 39/POJK.05/2014 Tentang Tata Kelola Perusahaan Yang Baik Bagi Perusahaan Pembiayaan.

Otoritas Jasa Keuangan sebagai lembaga yang bertugas untuk melindungi konsumen dalam sektor jasa keuangan yang dalam hal ini peer to peer lending, sudah seharusnya membuat pengaturan mengenai penggunaan debt collector dan tata cara penagihan oleh debt collector dalam melakukan penagihan pinjaman gagal bayar peer to peer lending. Otoritas Jasa Keuangan dapat melakukan perubahan di dalam Peraturan Otoritas Jasa Keuangan No.77/POJK.01/2016 Tentang Layanan Pinjam Meminjam Berbasis Teknologi Informasi atau dapat membentuk suatu Peraturan Otoritas Jasa Keuangan baru. Hal tersebut merupakan suatu hal yang penting untuk diatur di dalam Peraturan Otoritas Jasa Keuangan agar terciptanya kepastian hukum bagi konsumen pengguna peer to peer lending.

\section{Penyelesaian Sengketa Terhadap Perbuatan Melawan Hukum yang dilakukan Oleh Debt Collector}

Mengacu pada Pasal 1365 Kitab Undang-Undang Hukum Perdata, konsumen yang merasa dirugikan atas kesalahan yang dilakukan debt collector dapat meminta ganti rugi sebagaimana disebutkan dalam Pasal 1365 Kitab Undang-Undang Hukum Perdata:

\footnotetext{
17 Asosiasi Fintech Pendanaan Bersama Indonesia (AFPI), "Pedoman Perilaku Pemberian Layanan Pinjam Meminjam Uang Berbasis Teknologi Informasi Secara Bertanggung Jawab”, diambil dari https://www.afpi.or.id/detailsnews/pedoman-perilaku

18 Ibid.

19 Ibid. hlm.11
} 
“Tiap perbuatan yang melanggar hukum dan membawa kerugian kepada orang lain, mewajibkan orang yang menimbulkan kerugian karena kesalahannya untuk menggantikan kerugian tersebut."

Agar dapat meminta ganti kerugian sebagaimana diatur pada Pasal 1365 Kitab Undang-Undang Hukum Perdata, debt collector tersebut harus memenuhi unsurunsur perbuatan melawan hukum.

Unsur-unsur perbuatan melawan hukum yang harus dipenuhi agar dapat meminta ganti kerugian yaitu:

a. Adanya suatu perbuatan

Perbuatan adalah berbuat sesuatu atau tidak berbuat sesuatu. ${ }^{20}$ Perbuatan tersebut tidak harus perbuatan yang disengaja tetapi juga kelalaian atau kealpaan yang menimbulkan kerugian. ${ }^{21}$

b. Perbuatan tersebut melawan hukum

Perbuatan tersebut melawan hukum apabila berlawanan dengan hak orang lain, kewajiban hukumnya sendiri, kesusilaan yang baik, keharusan yang diindahkan dalam pergaulan hidup masyarakat mengenai orang lain atau benda. ${ }^{22}$

c. Perbuatan tersebut menimbulkan kerugian

Kerugian pada perbuatan melawan hukum tidak hanya kerugian secara materiil saja tetapi juga mencakup pada kerugian secara immateriil. Kerugiaan immateriil yaitu tidak berkurangnya harta kekayaan melainkan kerugian tersebut dapat berupa ketakutan, kehormatan ataupun kesenangan dalam hidup. ${ }^{23}$

d. Adanya hubungan kasual (sebab-akibat) antara perbuatan dengan kerugian Hubungan kasual merupakan hubungan sebab akibat antara perbuatan melawan hukum dengan kerugian. Kerugian itu harus timbul sebagai akibat dari perbuatan seseorang, jika tidak ada perbuatan (sebab) maka tidak ada kerugian (akibatnya). ${ }^{24}$

e. Adanya kesalahan

Kesalahan yang terdapat di dalam perbuatan melawan hukum tidak hanya perbuatan yang dilakukan dengan sengaja melainkan suatu perbuatan yang dilakukan karena kelalaian seseorang.

Penyelesaian sengketa berdasarkan Pasal 39 (1) Peraturan Otoritas Jasa Keuangan No.1/P0JK.07/2013 Tentang Perlindungan Konsumen Sektor Jasa Keuangan konsumen dapat melakukan pengaduan kepada lembaga jasa keuangan terkait yaitu penyelenggara peer to peer lending (internal dispute resolution). Berdasarkan Pasal 32 (1) Peraturan Otoritas Jasa Keuangan No.1/POJK.07/2013 Tentang Perlindungan Konsumen Sektor Jasa disebutkan bahwa pelaku usaha jasa keuangan wajib memiliki dan melaksanakan mekanisme pelayanan dan penyelesaian pengaduan bagi Konsumen.

Surat Edaran OJK Nomor: 2/SEOJK.07/2014 tentang Pelayanan dan Penyelesaian Pengaduan Konsumen Pada Pelaku Usaha Jasa Keuangan menyebutkan bahwa Penyelesaian Pengaduan dapat Berupa Pernyataan Maaf Atau Menawarkan Ganti Rugi (Redress/Remedy) antara Pelaku Usaha Jasa Keuangan dan Konsumen. Konsumen yang dapat diberikan ganti kerugian adalah kerugian yang terjadi karena aspek finansial dan harus memenuhi persyaratan sebagai berikut:

\footnotetext{
${ }^{20}$ Munir Fuady, Perbuatan Melawan Hukum: Pendekatan Kontemporer, hlm. 36

21 Ibid.

22 P.N.H Simanjuntak, Hukum Perdata Indonesia, hlm.304

${ }^{23}$ Rachmat Setiawan, Tinjauan Elementer Perbuatan Melawan Hukum, hlm. 85-85

24 Ibid. hlm. 305
} 
a. terdapat pengaduan yang mengandung tuntutan ganti rugi yang berkaitan dengan aspek finansial;

b. pengaduan Konsumen yang diajukan adalah benar, setelah PUJK melakukan penelitian;

c. adanya ketidaksesuaian antara perjanjian produk dan/atau layanan dengan produk dan/atau layanan yang diterima;

d. adanya kerugian material;

e. Konsumen telah memenuhi kewajibannya.

Sehingga konsumen yang mengalami kerugian immateriil berdasarkan surat keputusan OJK tersebut tidak dapat memintakan ganti kerugian.

Selain pengaduan kepada penyelenggara peer to peer lending, konsumen juga dapat melakukan pengaduan kepada Asosiasi Fintech Pendanaan Bersama Indonesia (AFPI). Pengaduan dapat dilakukan melalui website AFPI yaitu https://afpi.or.id/pengaduan dan mengisi form yang telah tersedia. Pengaduan melalui AFPI nantinya akan diproses dengan menindaklanjuti pengaduan tersebut dan jika terbukti terdapat pelanggaran yang melanggar pada pedoman perilaku maka penyelenggara akan memberikan sanksi sesuai dengan prosedur pengenaan sanksi oleh Majelis Etika Asosiasi setelah berkonsultasi dengan Otoritas Jasa Keuangan, sanksi tersebut antara lain ${ }^{25}$ :

a. Teguran tertulis

b. Publikasi nama anggota dan ketentuan yang dilanggar Otoritas Jasa Keuangan kepada masyarakat

c. Pemberhentian sementara dari keanggotaan asosiasi

d. Pemberhentian tetap dari keanggotaan asosiasi

Tahapan yang kedua berdasarkan Pasal 39 (1) Peraturan Otoritas Jasa Keuangan No.1/POJK.07/2013 Tentang Perlindungan Konsumen Sektor Jasa Keuangan konsumen adalah penyelesaian sengketa melalui di luar pengadilan atau pengadilan (external dispute resolution). Jika pada tahap pertama tidak mencapai kesepakatan antara konsumen dan penyelenggara peer to peer lending maka dapat memilih untuk menyelesaikan sengketa melalui di luar pengadilan yaitu melalui Lembaga Alternatif Penyelesaian Sengketa (LAPS) yang disediakan oleh Otoritas Jasa Keuangan atau pengadilan.

Konsumen dapat lebih memilih LAPS sebagai alternative penyelesaian sengketa dikarenakan prosedur yang cepat, berbiaya murah dan dengan hasil obyektif, relevan dan adil. Penyelesaian sengketa melalui LAPS juga bersifat rahasia sehingga antara konsumen dan pelaku usaha jasa keuangan akan lebih nyaman. Layanan penyelesaian sengketa di LAPS dapat melalui Mediasi, Ajudikasi dan Arbitrase, namun tidak dapat menempuh jalur Ajudikasi dan Arbitrase jika sebelumnya tidak melalui jalur Mediasi.

Langkah pertama yang harus dilakukan oleh konsumen adalah menyampaikan permohonan penyelesaian sengketa kepada lembaga independen yang terdaftar dalam LAPS serta diawasi OJK, perihal belum adanya LAPS dalam peer to peer lending maka dapat mengajukan permohonan kepada Otoritas Jasa Keuangan. LAPS saat ini telah memiliki enam Daftar Lembaga Alternatif Penyelesaian Sengketa di Otoritas

\footnotetext{
25 Asosiasi Fintech Pendanaan Bersama Indonesia (AFPI), "Pedoman Perilaku Pemberian Layanan Pinjam Meminjam Uang Berbasis Teknologi Informasi Secara Bertanggung Jawab”, diambil dari https://www.afpi.or.id/detailsnews/pedoman-perilaku
} 
Jasa Keuangan antara lain Badan Mediasi dan Arbitrase Asuransi Indonesia (BMAI), Badan Arbitrase Pasar Modal Indonesia (BAPMI), Badan Mediasu Dana Pensiun (BMDP), Badan Arbitrase dan Mediasi Perusahaan Penjaminan Indonesia (BAMPPI), Lembaga Alternatif Penyelesaian Sengketa Perbankan Indonesia (LAPSPI) dan Badan Mediasi Pembiayaan dan Pergadaian Indonesia (BMPPI). ${ }^{26}$

Otoritas Jasa Keuangan akan melakukan verifikasi dan memberikan konfirmasi terhadap dokumen permohonan. Selanjutnya, konsumen dan penyelenggara peer to peer lending dalam tahap mediasi akan menunjuk dan menentukan mediatornya sendiri. Mediator hanya untuk memfasilitasi dan mengupayakan perdamaian antara kedua belah pihak. Jika mencapai kesepakatan antara konsumen dan penyelenggara peer to peer lending maka akan dibuatkan Akta Perdamaian serta nantinya Otoritas Jasa Keuangan akan melakukan monitoring terhadap pelaksanaan kesepakatan. Jika pada tahap mediasi tidak juga mencapai kesepakatan maka ditempuh melalui upaya ajudikasi dan arbitrase.

Konsumen juga dapat memilih penyelesaian sengketa melalui pengadilan yang dilakukan di Pengadilan Negeri. Berdasarkan Pasal 39 (3) Peraturan Otoritas Jasa Keuangan No.1/P0JK.07/2013 Tentang Perlindungan Konsumen Sektor Jasa Keuangan konsumen disebutkan bahwa Otoritas Jasa penyelesaian sengketa yang dilakukan diluar Alternatif Penyelesaian Sengketa, konsumen dapat menyampaikan permohonan kepada Otoritas Jasa Keuangan untuk memfasilitasi konsumen yang merasa dirugikan oleh pelaku usaha jasa keuangan.

Prosedur penyelesaian sengketa di Pengadilan Neegeri tunduk pada ketentuan hukum prosedur formal sebagaimana diatur di dalam HIR. Prosedur pengajuan gugatan melalui pengadilan yaitu seseorang yang merasa haknya telah dirugikan (penggugat) oleh pihak lain (tergugat) dapat menghadap secara pribadi atau diwakili oleh orang lain/kuasanya untuk mengajukan gugatannya kepada ketua pengadilan negeri sesuai dengan daerah hukum tergugat bertempat tinggal. ${ }^{27}$ Gugatan pada prinsipnyaa diajukan secara tertulis, tetapi apabila penggugat tidak dapat menulis maka dapat diajukan gugatan secara lisan kepada ketua pengadilan. ${ }^{28}$ Gugatan disampaikan kepada Pengadilan Negeri, kemudian akan diberikan nomor dan didaftarkan dalam buku register setelah membayar panjar biaya perkara yang besarnya ditentukan oleh Pengadilan Negeri. ${ }^{29}$

Menurut mantan hakim Susanti Adi Nugroho terdapat kritik pada penyelesaian sengketa melalui pengadilan yaitu penyelesaian sengketa melalui pengadilan yang lambat, biaya perkara yang mahal, putusan peradilan sering tidak menyelesaikan masalah dan kemampuan hakim yang generalis. ${ }^{30}$ Berdasarkan beberapa pertimbangan, penyelesaian sengketa melalui LAPS lebih memiliki keunggulan dibandingkan dengan melalui pengadilan maka lebih baik konsumen melakukan penyelesaian sengketa melalui LAPS.

${ }^{26}$ Edukasi dan Perlindungan Konsumen, "Lembaga Alternatif Penyelesaian Sengketa", diambil dari https://www.ojk.go.id/id/kanal/edukasi-dan-perlindungan-konsumen/Pages/Lembaga-Alternatif-

PenyelesaianSengketa.aspx

27 Pasal 118 HIR

28 Pasal 120 HIR

${ }^{29}$ Pasal $121 \mathrm{HIR}$

${ }^{30}$ Susanti Adi Nugroho, Penyelesaian Sengketa Arbitrase dan Penerapan Hukumnya, hlm. 5-6 sebagaimana dikutip dalam Ema Rahmawati dan Rai Mantili, "Penyelesaian Sengketa Melalui Lembaga Alternatif Penyelesaian Sengketa di Sektor Jasa Keuangan”, PADJADJARAN Jurnal Ilmu Hukum hlm. 245 
Penyelenggara peer to peer lending yang terbukti bersalah atas terjadinya penagihan secara sewenang-wenang dilakukan oleh debt collectornya dapat dikenakan sanksi oleh AFPI. Berdasarkan Pasal 47 Peraturan Otoritas Jasa Keuangan No.77/POJK.01/2020 Tentang Layanan Pinjam Meminjam Berbasis Teknologi Informasi Informasi Otoritas Jasa Keuangan juga dapat mengenakan sanksi administrative berupa peringatan tertulis, denda, pembatasan kegiatan usaha dan pencabutan izin.

\section{PENUTUP}

Pengaturan terkait dengan penggunaan debt collector dalam melakukan penagihan pada peer to peer lending belum diatur oleh Otoritas Jasa Keuangan, hal tersebut hanya diatur di dalam Pedoman Perilaku yang dibuat oleh AFPI. Tidak diaturnya terkait penggunaan debt collector menimbulkan kedudukan hukum yang tidak jelas dan ketidakpastian hukum bagi pengguna peer to peer lending. Oleh karena itu, Otoritas Jasa Keuangan berkewajiban untuk membentuk suatu Peraturan Otoritas Jasa Keuangan terkait dengan penggunaan debt collector dan tata cara penagihan oleh debt collector dalam melakukan penagihan pinjaman gagal bayar peer to peer lending walaupun telah menunjuk AFPI untuk membentuk pedoman perilaku agar terciptanya kepastian hukum. Penyelesaian sengketa khususnya pada peer to peer lending diharapkan bagi Otoritas Jasa Keuangan segera membentuk Lembaga Alternatif Penyelesaian Sengketa pada bidang peer to peer lending.

\section{DAFTAR PUSTAKA}

\section{Peraturan Perundang-Undangan}

Kitab Undang-Undang Hukum Perdata

Undang-Undang No.21 Tahun 2011 Tentang Otoritas Jasa Keuangan

Peraturan Otoritas Jasa Keuangan No.1/POJK.07/2013 Tentang Perlindungan Konsumen Sektor Jasa Keuangan

Peraturan No.77/POJK.01/2016 Tentang Layanan Pinjam Meminjam Berbasis Teknologi Informasi

\section{Buku}

Fuady, Munir. 2005. Perbuatan Melawan Hukum: Pendekatan Kontemporer. Cetakan Kedua. PT Citra Aditya. Bandung.

Soekanto, Soerjono dan Mamudji, Sri. 2001. Penelitian Hukum Normatif (Suatu Tinjauan Singkat). Cetakan ke-17. Jakarta. Rajawali Pers.

Simanjuntak, P.N.H. 2017. Hukum Perdata Indonesia. Edisi Pertama. Cetakan ke-4. KENCANA. Jakarta.

Setiawan, Rachmat. 1982. Tinjauan Elementer Perbuatan Melawan Hukum. Alumni Bandung. Bandung.

Zulham. 2013. Hukum Perlindungan Konsumen. Cetakan ke-1. Jakarta. Kencana.

\section{Artikel Jurnal Melalui Website}

Murti, Sari dan Widijantoro, Johanes. 2019. The Role Of Financial Services Authority In The Consumer Protection Amid The Growth Of Fintech Industry In Indonesia. 


Mimbar Hukum. 31(2): 229. Retrieved from
https://jurnal.ugm.ac.id/jmh/article/view/43129/25630

Rahmawati, Ema dan Mantili, Rai. 2016. Penyelesaian Sengketa Melalui Lembaga Alternatif Penyelesaian Sengketa di Sektor Jasa Keuangan. PADJADJARAN Jurnal Ilmu Hukum. 3(2): 240-260. Retrieved from http://jurnal.unpad.ac.id/pjih/article/view/9546/5399

\section{Website}

Asosiasi Fintech Pendanaan Bersama Indonesia (AFPI). 2019. Pedoman Perilaku Pemberian Layanan Pinjam Meminjam Uang Berbasis Teknologi Informasi secara Bertanggung Jawab. https://www.afpi.or.id/detailsnews/pedoman-perilaku. 26 Desember 2019.

Departemen Perlindungan konsumen. 2017. Kajian Perlindungan Konsumen Sektor Jasa Keuangan: Perlindungan Konsumen Pada Fintech. https://konsumen.ojk.go.id/MinisiteDPLK/images/upload/20180713145126 \%20Fintech.pdf. 23 Desember 2019.

Edukasi dan Perlindungan Konsumen. Lembaga Alternatif Penyelesaian Sengketa. https://www.ojk.go.id/id/kanal/edukasi-dan-perlindungan konsumen/Pages/Lembaga-Alternatif-PenyelesaianSengketa.aspx. 24 Maret $\underline{2020 .}$

Lembaga Pengembangan Perbankan Indonesia. 2019. Peer to Peer Lending (P2P) Pelajaran Dari China.

http://lppi.or.id/site/assets/files/1424/a 12 fintek di china.pdf. 26 Desember 2019.

Ryza, Prayogo. 2019. AFPI Ditunjuk OJK Sebagai Asosiasi Resmi Penylenggara Layanan P2P Lending. https://dailysocial.id/post/afpi-resmi-p2p-lending. 8 Mei 2020 
